\title{
The encounter of two cultural identities: The case of social deixis
}

\author{
Magdaléna Bilá, Alena Kačmárová and Ingrida Vaňková \\ University of Prešov in Prešov \\ Prě̌ov, Slovakia
}

\begin{abstract}
In contact with foreign environment, the encounter of two (or more) cultures is common in situations with an incompatible cultural aspect. A typical example is T-V distinction. In most languages, mainly European ones, conveying social deixis oscillates between two poles: $\mathrm{T}$ and $\mathrm{V}$ forms. Present-day English is the only mainstream language with the absence of morphological markers for conveying $\mathrm{T} / \mathrm{V}$ relationships. The present research examines the concept of expressing social distance in Slovak and in English, languages respectively having and lacking overt T/V markers, in order to specify the distinctiveness of English vs. Slovak lingua-cultural identity and/or discursive practice of the respective culture with regard to expressing social distance. This is done in two steps. Firstly, the underlying concepts (a lingua-cultural identity, social distance, $\mathrm{T} / \mathrm{V}$ forms) are studied by means of the conceptualizing scheme (Kačmárová, Bilá, Vaňková 2018); its essence lies in accounting for and in aligning four sub-processes: frame establishment, encoding (pre-understanding), contextualization (salience), and code configuration. The conceptualization process utilized a set of principles (adopted from Clyne, Norrby \& Warren 2009). Secondly, based on the theoretical results, the questionnaires were designed. The questions for native speakers of Slovak examined the preferences in the usage of T vs. V forms; the questions for native speakers of English examined the preferences in the usage of informal vs. formal ways of communication. The present study indicates that the conceptualizing process may as well be of hierarchical nature. Thus, the mere conceptualization of $\mathrm{T}$ vs. $\mathrm{V}$ or informal vs. formal may emanate from the conceptualization of social distance in terms of a set of principles, the conceptualization of the specific principle in terms of the relationship types, the conceptualization of the relationship type in terms of a specific culture and the conceptualization of a culture-specific relationship type through language means ( $\mathrm{T}$ or $\mathrm{V}$ ).
\end{abstract}

Keywords: lingua-cultural identity, social distance, power and solidarity, $T / V$ forms, native speakers of English, native speakers of Slovak

\section{For citation:}

Bilá, Magdaléna, Alena Kačmárová and Ingrida Vaňková. 2020. The encounter of two cultural identities: The case of social deixis. Russian Journal of Linguistics 24 (2). 344-365. DOI: 10.22363/2687-0088-2020-24-2-344-365 
Научная статья

\title{
Проявление культурной идентичности в социальном дейксисе
}

\author{
Магдалена Била, Алена Качмарова и Ингрида Ванькова
}

\author{
Прешовский университет в Прешове \\ Прешов, Словакия
}

\begin{abstract}
Аннотация
В межкультурных контактах неизбежно проявляются различия, особенно в ситуациях, где расхождения предопределяются культурой. Типичным примером является передача ты/Вы отношений. В большинстве языков, в основном европейских, передача социального дейксиса колеблется между двумя полюсами: ты/Вы формами. Современный английский язык является исключением, так как в нем отсутствуют морфологические маркеры для передачи отношений ты/Вы. В данном исследовании рассматривается выражение социальной дистанции в словацком и английском языках, т.е. в языках, один из которых имеет, а другой не имеет ты/Вы маркеров. Цель исследования - определить различия между английской и словацкой лингвокультурными идентичностями и/или дискурсивными практиками соответствующих культур в отношении выражения социальной дистанции. Исследование проводилось в два этапа. Сначала были изучены базовые понятия (лингвокультурная идентичность, социальная дистанция, ты/Вы формы), для чего была привлечена концептуализирующая схема (Kačmárová, Bilá, Vaňková 2018), суть которой заключается в учете и согласовании четырех процедур: установление рамок, кодирование (предварительное понимание), контекстуализация и кодовая конфигурация. В процессе концептуализации использовался набор принципов, взятых из Clyne, Norrby \& Warren 2009. На втором этапе, на основе полученных теоретических результатов, были разработаны анкеты. Вопросы для носителей словацкого языка отражали предпочтения в использовании ты/Вы форм; вопросы для носителей английского языка отражали предпочтения в использовании неформальных и формальных способов общения. Данное исследование показывает, что процесс концептуализации также может иметь иерархическую природу. Простая концептуализация ты/Вы форм или формальности/неформальности может вытекать из концептуализации социальной дистанции на основе набора принципов, концептуализации конкретного принципа исходя из типа отношений, концептуализации типа отношений в рамках конкретной культуры и концептуализации культурно-специфичного типа отношений через языковые средства (ты или Вы).
\end{abstract}

Ключевые слова: лингвокультурная идентичность, сочиальная дистанциия, власть и солидарность, ты/Вы формы, носители английского языка, носители словачкого языка

\section{Для цитирования:}

Bilá, Magdaléna, Alena Kačmárová and Ingrida Vaňková. 2020. The encounter of two cultural identities: The case of social deixis. Russian Journal of Linguistics 24 (2). 344-365. DOI: 10.22363/2687-0088-2020-24-2-344-365

\section{Introduction}

Once conducted research on expressing social deixis in two languages led to an important conclusion that serves as a research problem in the present study. The study concerned (Bilá, Kačmárová \& Kraviarová 2018) dealt with expressing interpersonal relationships, namely $\mathrm{T}$ and V (tous vs. vous) address in Slovak and in English based on phonic realization of utterances. We compiled a corpus of 
utterances spoken in everyday situations, categorized them based on socially acceptable principles for $\mathrm{T}$ and $\mathrm{V}$ distinction, and subdivided them into two subcorpora (utterances complying with $\mathrm{T}$-form and those complying with $\mathrm{V}$-form lingua-cultural behavior). As a result, we obtained unbalanced corpora in that the latter was significantly lower in number. The important finding (and the tentative research problem) is that the American culture seems to apply the model of "dispersion" rather than bipolarity, which makes it an intricate task to identify V (vous) encounters.

Thus, we consider it an issue worth investigation to find out what principles are applied in the decision-making process in addressing someone through $\mathrm{T}$-forms or V-forms. The two inherently imply different concepts in the two cultures: in Slovak, it may well be a grammatical concept (due to adopting morphological means) and is closely associated with politeness marking ( $c f$ Rhee 2019); in English, it may as well be a socio-pragmatic and lexical concept (due to adopting other than morphological means). We argue that examining the concept of expressing social distance in languages with and without overt grammatical $\mathrm{T} / \mathrm{V}$ markers must consider what the speaker is committed to in interaction (Haugh 2013: 41): "A speaker means something by intending that the hearer recognise what is meant as intended by the speaker," but also, the speaker is held accountable to the moral order for what he or she is taken to mean in interaction. The notion of speaker meaning must be delineated by culturally conventionalized sets of principles of linguistic and non-linguistic behavior.

The present study aims to specify the distinctiveness of English vs. Slovak lingua-cultural identity and/or discursive practice of the respective culture with regard to expressing social distance. The underlying concepts of this study include the concepts of a lingua-cultural identity, social distance, discursive practices, and a multilingual and a multilingual's mind. These concepts are tackled and our understanding of their standing in the present study is presented in the second section. The methodology of research including the aim, research questions, a research plan, utilized methods and tools make part of the third section. The research findings are given and commented on in the fourth section.

\section{The research underlying concepts}

\subsection{Lingua-cultural identity and Social distance}

Anthropologists approach culture as something belonging to a particular society, something that makes that society different from others. Hall (1983) sees culture as an invisible mechanism controlling one's thoughts. Hofstede (1994) treats it as a representation of collective programming of the mind typical of a particular group of people. Spencer-Oatey (2004: 4) understands culture as “... a fuzzy set of attitudes, beliefs, behavioural norms, and basic assumptions and values that are shared by a group of people and that influence each member's behavior and his/her interpretation of the 'meaning' of other people's behavior." One way or 
another, we deal with a sense of (lingua)cultural identity developed under certain circumstances and conventionalized over time, which is pertinent to a specific lingua-cultural community.

Within the anthropocentric (Vaňko 2014) and socioconstructivist (Kirschner \& Martin 2010) paradigms, a lingua-cultural identity can be seen as a structure permanently created in the interaction of ' $\mathrm{I}$ - others - a lingua-culture'. Vignoles, Schwartz, and Luyckx (2011) argue that within any cultural environment and historical moment, identity categories, including a cultural identity, possess particular meanings established, structured and manifested through social discourse as a sum of everything that is said, written, talked about and represented in a given state of society. Therefore, one of the manifestations of lingua-cultural identity is linguistic behavior through which a language user verbalizes all concepts, values, and schemes of conduct practiced in a particular lingua-culture. An inherent part of a lingua-cultural identity is the experience-and-knowledge based competence to understand what is appropriate and inappropriate in their lingua-culture, what language means comply with unwritten rules of conduct (e.g. social distance, social deixis), what is allowed, what is already taboo. Succinctly, as Matos Lisboa and Leite de Oliviera (2017: 321) state, "identities are very complex, built through discourse." In a similar vein, the culture-based investigation views an identity as "historically and discursively constructed", as an entity which is fluctuating and not primeval (Moghadam 2018).

Comparing the verbalization of social distance and social deixis in English and Slovak, significant discrepancies may be observed, mainly in the presence vs. absence of their expression through morphological means. The lack of morphological means in English serving as a "corridor" for the present-day linguacultural behavior may not directly source from the suppression of detailed stratification of relationships. Although the verbalization of social stratification in English through pronominal and morphological means is much simpler than in Slovak, a detailed socio-linguistic analysis may reveal other distinctive channels and means through which social distance is expressed and verbalized.

When clarifying the discrepancies in the conceptualization of social stratification in English and Slovak, it is necessary to draw on the delineation of singular "you" in English and "ty/vy" (T/V form) in Slovak as linguistic signs, i.e. semiotic concepts understood in the semiotic-cognitive-axiological interspace. A useful approach may as well be the considering of the relationship of referential and contextual meaning types. The concept of respect is the semantic feature of the referential lexico-grammatical meaning of $\mathrm{V}$-form as a 'respectful you' operating also at the level of connotative meaning; $\mathrm{V}$-form is typical for the children/teenagers-to-elderly conversations, formal situations, and small talks (which are generally of formal nature).

The conceptualization of social distance through singular "you" in English is structured as the fusion of its referential and contextual meaning with the predominance of contextual meaning. With regard to its referential meaning 
singular 'you' refers to a single recipient. The overall meaning of this personal pronoun expressing and encompassing concepts of respect and familiarity is comprehensively structured in its contextual meaning through the deployment of other language means within the immediate linguistic environment.

In Slovak, social distance is also conceptualized as the fusion of referential and contextual meaning, however with the predominance of referential meaning. The concept of social distance is an intrinsic part and a semantic feature of both T-form and V-form referential lexico-grammatical meanings. The basic semantic feature identified within the semantic structure of referential and lexico-grammatical meaning of T-form is familiarity operating also at the level of connotative meaning in the sense of stylistic reference of T-form and its emotional coloring. The usage of the T-form thus may be observed in encounters within family, among friends and as part of child-to-child, teenager-to-teenager, or the elderly-to-children/teenagers conversations.

The usage of $\mathrm{T} / \mathrm{V}$ forms in Slovak uncovers unwritten rules conventionalized within the lingua-culture. To exemplify the most interesting ones, several situations may be described. During an adult-to-person-under-18 conversation, an adult can use 'familiar you' ( $T$-form), while a young person is supposed to adhere to 'respectful you' (V-form). The transition from V-form to T-form in conversation between strangers implies a shift in their relationship towards a closer friendship or a more relaxed relationship. Such a development may be observed also in relations among work associates, with the exception of business talks and negotiations, during which the social distance of superiority is established either through V-form and/or other language means. Linguistic behavior of Slovak native speakers unveils that the decision for $\mathrm{T}$ - or $\mathrm{V}$-form highly depends on the level of acquaintance, level of familiarity, or gender (e.g. at work, it is more typical of men-to-men to start firstname relationship sooner than of woman-to-woman or man-to-woman relationship).

\subsection{Discursive practice}

The use of language in a variety of settings, discourse, is viewed upon as a three-dimensional concept: as text, discursive practice, and social practice (Fairclough 1992). As social practice, the use of language is entrenched in social and historical environment, participates in the social structuring of reality, in the social modeling of a community, in the crafting of social identities, in the modelling of social relations and in the generating of intricate discursive practices and discourse conventions (Resta 1998, Van Dijk 2006). Discursive practices are responsible for configuring discursive commitment. Since discursive commitment (on the term, $c f$ Brandom 1994) becomes socially consequential, it abides by cultural norms, hence relies on conventionalized communication styles. For this reason, speaker meaning may as well embody social commitment, which as a matter of fact is culture-sensitive. 
Discursive practice, a "poststructuralist term, denotes the way in which a discourse is acted on and circulated within a culture" (online, behavenet). Foucault $(2001,2010)$ understands discursive practices as the indicators of power relations in the society and routines in which a power relationship is created by enhancing it through the use of language. The power relationship is then revealed through a range of practices such as speech styles which include lexis, morphosyntactic structures, intonation, forms of address, naming strategies, etc. The discursive practices thus signify and through their recurrence eventually confirm the social status of the speakers thus pointing to social stratification in a society (Chiluwa 2010). "Discursive practice' represents how discourse is involved in the construction of social and cultural practice including beliefs, knowledge, religion, norms and values" (Chiluwa 2010: 113).

Discursive practices further translate in "linguistic behavior, an aspect of culture conceptualized as a blend of inborn and acquired individual traits operating in communication and manifested in the attitude to the language and linguistic activity" (Valeyeva 2014: 986). Learned or acquired (i.e. extrasomatic or extragenetic) behavior may just as well be referred to as cultural behavior. In linguistic and cultural behavior, the principles, rules, values and narratives of a given cultural community are repeatedly (overtly or covertly) exhibited, strengthened, and authorized. Thus, they transform into cultural patterns which are transmitted to future generations, maintain and sustain the culture in question. In such a manner, language use and discursive social interaction contribute to the development of cultural identities and cultural sensitivity (Komlósi 2003).

Cultural embeddedness of discursive practices and social dependence of social commitment represent one of the troublesome areas for anybody involved in intercultural communication. Effective intercultural communication presupposes much more than the mere knowledge of L2 lexis and grammar, the means of social deixis considered appropriate and polite in one linguacultural community may be inappropriate and impolite in another. Hence, acquaintance with the culturally appropriate L2 discursive practices is of major importance. As generally acknowledged, there is a reciprocal and complex relationship between language and culture in that a language mirrors a community's cultural features and "constitutes cognitive and affective coherence in the social reality of culture whereas culturalsocietal phenomena secure the grounding of meaning in language and lend meaning-contents to linguistic expressions. [...] Knowledge of the extra-linguistic world gets delicately integrated into detailed and fine-grained linguistic knowledge" (Komlósi 2003: 163).

There is ample evidence that comprehending an utterance (especially in L2) requires the involvement of several mental domains representing different knowledge sources (Komlósi 2003). A typical example is English and Slovak (together with other languages): the latter possess(es) pronominal and morphological means of social deixis; the former lacks such elements. Hence, the underlying question is whether or not native speakers of a language lacking overt 
markers of social deixis (lexical or morphological) have such a frame in their minds. As mentioned above, social deixis is necessarily linked with culture-specific discursive commitment. However, it is necessary to seek answers to questions like what commitment rules in expressing social deixis exist and what conventional (or rather conventionalized, as it were) means or discursive practices allow a hearer access the speaker's commitment. Unveiling discursive practices and social commitment rules in L2 culture can as well provide hints for linguistic behavior of a speaker raised in an L1 culture.

\subsection{A Multilingual and a Multilingual's Mind}

The number of countries largely differs from the number of languages, which makes us think that many languages get in contact. Consequently, many people are exposed to more than a single language. Hence, bilingualism (or multilingualism) is a natural part of everyday life (Kortvélyessy 2010: 44-45). The practice of alternately using two (or more languages) is the basis for all subsequent treatments of bi-/multilingualism. In defining a bi-/multilingual, different theories consider based on whether they account for origin, competence, function (self)identification, age, context, approach, order and sequence. Hoffman (1991: 18) states seven factors that influence bilingualism, and recognizes subtypes within each, namely: age, context, the relationship between a sign and a meaning, order and sequence, competence, function, and approach.

Grosjean (1985: 24) holds a holistic view of bilingualism which "proposes that the bilingual is an integrated whole which cannot easily be decomposed into two separate parts." A multilingual's identity is not only a matter of personal identity but is greatly influenced by the sociocultural context. It is a structure created in line with how people interpret their contact with reality. It is permanently shaped by socialization and individualization followed by individuation, i.e. interpersonal contact with appropriate communication partners on appropriate topic in appropriate situations at appropriate times. It becomes realized in such kind of discourse that involves a balanced share of elements studied by (social) psychology, anthropology, and philosophy. The three perspectives work in synergy.

(Social) psychology suggests the usage of language as an artifact of culture. This implies that a human being is a creator of meaning, a self-interpretive being. Hence, identity is constructed through cultural symbols and traditions. As a matter of fact, culture comprises all artifacts and practices accumulated by a particular community through its historical development. The perspective of anthropology implies that communication involves a deep-rooted plan of non-conscious norms and structures of thinking (non-conscious in the sense of automatic, routine). A cultural sign can be understood as a representation of an unconscious thought structure of a cultural phenomenon. Cultural signs cannot be studied as autonomous entities; they fall into a set of syntagmatic and paradigmatic relations, and through their presence in these relations they obtain a specific meaning. The philosophybased view advocates that the identity of 'I' need be considered within the domain 
of self-interpretation since 'I' cannot exist on its own. Taylor (1985) claims that a language is not a mere cluster of discrete tools; it is a network, and in each part of the network a whole is represented. Thanks to people's ability to use language, they are responsible for sharing meaning and experience in the incessant creation of a language. This process is constant - people can never capture a language in all its complexity.

In a language, a speaker, text, and socio-cultural context are put into mutual relationship. Ricoeur's $(1974,1976)$ understanding of discourse is such that even though a language is a prerequisite for communication, it is in discourse that the exchange of messages actually happens. A language does not entail a world; however, a discourse always revolves around a subject-matter. This leads Ricoeur (ibid) to believe that a language is a mediator between meaning (as the outcome of an activity) and discourse (as an event). Discourse is linked with a person (the speaker) illustrating the dialectal relationship between an event and meaning.

After one's exposure to a different culture, we start to notice differences and start to consciously contemplate other people's linguistic behavior ( $c f$. Larina 2015; Larina, Ozyumenko, Kurteš 2017). The mind of a monolingual/monocultural person continuously changes to that of a bi-/multilingual or bi-/multicultural. This change lies in the change of the nature of the so-called common underlying conceptual base (Kecskes \& Papp 2000: 42): "the full acquisition and proper use of a concept requires the learner to know not only its lexical-semantic counterpart and associated declarative knowledge but also the multimodal mental representation and culturally based behavioral scripts and schemas that are required through genuine communication." In the course of change from a monolingual/monocultural to a multilingual/multicultural, the configuration of language-culture-identity element is altered. It culminates with the stage of individuation seen as a unique quality attributable to multicompetence. Its essence is conceptualization. In the present study, we implement the four-item conceptualization scheme to identify a lingua-cultural identity and/or discursive commitment with regard to expressing social distance.

\section{Research methodology}

The research questions that we ask are as follows:

1. What is embodied in the concept of social distance and/or (in)formality in communication in a specific lingua-cultural identity?

2. What are the implications in case the encounter of two cultural identities occurs?

We look for the answers to these questions through implementing the conceptualization scheme (Kačmárová, Bilá \& Vaňková 2018). In our approach, the process of conceptualizing comprises four constituents that all together yield the conceptualization of a particular language unit or phenomenon: frame establishment, pre-understanding, salience, and code configuration. Frame establishment represents a field or a higher-order principle that the language 
unit/phenomenon is part of. Pre-understanding stands for defining the meaning, preconceptual knowledge of cultural/linguistic systems and codes. Salience embodies example usage of the language phenomenon in a specific context. Code configuration signifies considering a language pair within which a semantic equivalent is searched for, or the way that will enable us to identify a semantic equivalent (Bilá et al 2018, Kačmárová, Bilá \& Vaňková 2018). The idea that triggered this model was to provide information enhancing the deep structure rather than the surface structure of a language unit and/or phenomenon. This four-point model should guarantee that the actual conceptualization has taken place. We dare venture, only after the conceptualization is adopted, can the language phenomenon be appropriately approached and used with confidence.

The starting point is the concept of a lingua-cultural identity. If we take this term as a frame, we need to "dissect" it into pieces. To be able to do so, we adopt two tools: 1 / a set of principles of social distance, and 2 / a questionnaire. The former (adopted from Clyne, Norrby \& Warren 2009: 158) consists of six principles:

Familiarity principle: Do I know this person?

Maturity principle: Do I perceive this person to be an adult?

Relative age principle: Do I perceive this person to be considerably older/younger than me?

Network membership principle: Is the person a regular and accepted member within a group I belong to?

Social identification principle: Do I perceive this person to be similar or different from me?

Address mode accommodation principle: If this person uses $\mathrm{T} / \mathrm{V}$, or a $\mathrm{T} / \mathrm{V}$-like address with me, will I do the same?

The questionnaire was prepared in two versions; one for native speakers of Slovak, one for native speakers of English. The questionnaire was filled out by 51 respondents (25 NSS, $26 \mathrm{NSE}$ ), male and female, $21-67$ years of age, 30 years of age in average.

The research plan was as follows. First, we analyzed the concept of expressing social distance as a reflection of a lingua-cultural identity through implementing the four-point conceptualization scheme. In the applied scheme, the analyzed concept is considered in two directions - it is at once a conceptual hyponym and a conceptual hyperonym. For instance, if the concept under study is social distance, it is a conceptual hyponym to the concept of lingua-cultural identity and a conceptual hyperonym to $\mathrm{T} / \mathrm{V}$ forms of expressing relationships of power and solidarity. Secondly, based on the results obtained through the conceptualizing process, we designed the questionnaires. The questions for native speakers of Slovak examined the preferences in the usage of $T$ vs. $V$ forms. The questions for native speakers of English examined the preferences in the usage of informal vs. formal ways of communication. Thirdly, we analyzed the questionnaires. The process of conceptualizing and the analysis of questionnaire data is presented in Section 4. 


\section{Research findings}

\subsection{The analysis of the concept of social distance}

FRAME: The concept of social distance can be framed within the notion of linguacultural identity.

PRE-UNDERSTANDING: It is a culture-specific notion of one's position in a society expressed through the linguistic expression of person-to-person relationship, or power and solidarity concept. Social distance or closeness presupposes common ground between the interlocutors, which is to say the conceptual fluency of discursive routines typical of a particular lingua-cultural community.

SALIENCE: The typical means of expression is $\mathrm{T}$ (tous) or $\mathrm{V}$ (vous) forms in languages that have such forms in possession. It seems that English is the only major language that lacks overt morphological markers; however, it does not exclude the existence of social distance. The network of social relationships necessarily includes both $\mathrm{T}$ and $\mathrm{V}$ relations, their linguistic expression just differs from that in the languages with overt morphological markers.

CODE CONFIGURATION: The used morphological and lexical markers of the T/V phenomenon must follow certain principles. It is necessary to identify these principles.

\subsection{The analysis of the concept of $T$ and $V$ forms}

FRAME: The concept of $\mathrm{T}$ and $\mathrm{V}$ forms is framed within the concept of social distance.

PRE-UNDERSTANDING: There must be some principles operating in each linguacultural community, yet of idiosyncratic nature.

SALIENCE: The principles that can explain discursive practices with regard to T/V relationships may as well be abundant in each culture. Still, a comprehensive framework will ease the present analysis. We opt for the set of principles proposed by Clyne, Norrby \& Warren (2009: 158): familiarity principle, maturity principle, relative age principle, network membership principle, social identification principle, address mode accommodation principle.

CODE CONFIGURATION: Each principle can be rephrased by means of targeted questions (see 3 Research Methodology). Within each principle, types of relationships can be identified.

\subsection{The analysis of the concept of principles}

\subsubsection{Familiarity principle}

FRAME: Principles for specifying verbal expression of social distance.

PRE-UNDERSTANDING: Familiarity principle implies how much I know the person I am talking to. On one side, this is based on the facts like how long I have known the person, how frequently I am in contact with the person. However, 
on the other side, we need to consider how close relationship I have developed with the person based on the level of trustworthiness or willingness to share personal information.

SALIENCE: The familiarity principle encompasses an array of relationships that can be identified within this concept. We can consider these relationships on a sliding scale from very formal to very informal. These include: acquaintance, friend, close/distant relative, co-worker, boss in the lower/higher management.

CODE CONFIGURATION: Every relationship type has particular distant features that make one consider an acquaintance not a friend, or a distant relative rather than a close relative. Some of these relationships are based on objective features like work affiliation, position in a family tree. Others may imply some subjective evaluation - somebody may be just a co-worker; somebody else may be more of a friend than just a co-worker. In addition, there might also be cultural differences in specifying the borderlines between certain relationships - someone who is a close relative in India may as well be a distant relative in Slavic cultures. The task is to realize the socio-cultural restraints in this respect.

Based on this code configuration, we specified the questionnaire tasks as follows: Please indicate in what situations you are most frequently on formal terms (and/or use V forms and adequate vocabulary) and in what situations you are most frequently on informal terms (and/or use $\mathrm{V}$ forms and adequate vocabulary). If it is hard for you to decide, as the ratio of such situations is balanced, please mark the "T/V" column. The situations are as follows:

1. The conversation partner is your ...

The respondents were supposed to provide answers for each of the following relationship types: acquaintance, friend, close friend, co-worker, boss in the lower/higher management, close relative, distant relative.

2. I have known the conversation partner ...

The respondents were supposed to provide answers for each of the following options: for a very long time, for a long time, for a short time, for a very short time.

The following results have been obtained (Table 1).

Table 1

Familiarity principle data

\begin{tabular}{|l|c|c|c|c|c|c|}
\hline & \multicolumn{2}{|c|}{ Formal } & \multicolumn{2}{c|}{ Informal } & \multicolumn{2}{c|}{ formal or informal } \\
\hline & NSS & NSE & NSS & NSE & NSS & NSE \\
\hline Acquaintance & $3.10 \%$ & $27.30 \%$ & $28.10 \%$ & $27.30 \%$ & $68.80 \%$ & $45.40 \%$ \\
\hline Friend & $0.00 \%$ & $9.10 \%$ & $100.00 \%$ & $81.80 \%$ & $0.00 \%$ & $9.10 \%$ \\
\hline Co-worker & $3.10 \%$ & $18.20 \%$ & $50.00 \%$ & $45.50 \%$ & $46.90 \%$ & $36.30 \%$ \\
\hline Boss-lower & $68.80 \%$ & $27.30 \%$ & $15.60 \%$ & $27.30 \%$ & $15.60 \%$ & $45.40 \%$ \\
\hline Close relative & $0.00 \%$ & $0.00 \%$ & $62.50 \%$ & $90.90 \%$ & $37.50 \%$ & $9.10 \%$ \\
\hline
\end{tabular}

Legend: NSS - native speakers of Slovak, NSE - native speakers of English, 
The research shows from balanced to almost identical results in the following relationship types: informal behavior when involved in a conversation with a close friend, formal in interaction with a boss (a representative of higher management) and also in interaction with a distant relative. The results worth further discussion are those regarding the concept of friend. Based on the obtained data, it follows that the notion of "friend" has different conceptualization for native speakers of Slovak than for native speakers of English, see Table 2.

Table 2

\section{The conceptualization of 'friend'}

\begin{tabular}{ll}
\hline $100.00 \%$ of native speakers of Slovak: & friend equals informal communication \\
\hline $81.80 \%$ of native speakers of English: & friend equals informal communication \\
$9.10 \%$ of native speakers of English: & friend equals formal communication \\
$9.10 \%$ of native speakers of English: & friend equals formal or informal communication
\end{tabular}

It follows that the notion of friend in English not necessarily implies informal relationship; the term friend is less intimate or more dispersed for the native speakers of English than for the native speakers of Slovak who took part in the survey. The conclusion is that the term 'friend' may as well be a culture-specific term necessitating further specification of its lingua-cultural parameters.

The criterion of length of relationship yielded the following results (Table 3).

Familiarity principle / length of relationship

\begin{tabular}{|l|c|c|c|c|}
\hline & Long formal & Long informal & Short formal & Short informal \\
\hline NSE & $27.30 \%$ & $72.70 \%$ & $72.70 \%$ & $27.30 \%$ \\
\hline NSS & $53.10 \%$ & $46.90 \%$ & $93.80 \%$ & $6.20 \%$ \\
\hline
\end{tabular}

Regarding a long relationship, the more common behavior in line with politeness principles is other than formal; regarding a short relationship, quasi default conduct may be considered other than informal. For this reason, it is interesting to observe the difference in the tinted areas of the table. They point to a tentative dissimilarity in the conceptualization of what short and long may mean and/or what effect such conceptualization has on the mere linguistic behavior of a particular lingua-cultural community.

\subsubsection{Maturity principle}

FRAME: Principles for specifying verbal expression of social distance.

PRE-UNDERSTANDING: Maturity principle implies the understanding of whether I perceive the person an adult. In some countries, it may imply a border when I am quasi-allowed to use $\mathrm{T}$ form and/or informal address, and since what age it is impolite or disrespectful to do so. 
SALIENCE: Maturity principle encompasses situations in which irrespective of the physical age of the conversation partner I consider or I do not consider him/her mature and adult and I express myself accordingly.

CODE CONFIGURATION: The task is to realize the socio-cultural restraints in this respect, i.e. how a particular culture linguistically treats mature and immature persons.

The questionnaire data show the contradictory tendency in the linguistic behavior between native speakers of English and native speakers of Slovak. If the native speakers of English were in a conversation with a person that they consider mature, $54.50 \%$ of them would behave informally and $9.10 \%$ formally. If the native speakers of Slovak, were in a conversation with a person that they consider mature, $6.30 \%$ of them would behave informally and $53.10 \%$ formally.

\subsubsection{Relative age principle}

FRAME: Principles for specifying verbal expression of social distance.

PRE-UNDERSTANDING: Relative age principle implies considering whether I perceive my communicative partner to be of (approximately) my age or (considerably) older/younger than me. The principle draws on verbal behavior principles which humans as sociocultural beings have developed in socialization and social interaction. In socialization, the process by which the values, patterns of behavior, attitudes, and skills are considered as culturally appropriate, many agents are involved (family, peers, education, the media) and operate jointly rather than separately (Leidy \& Parke 2015). These processes are responsible for legitimizing and institutionalizing the communication norms pertaining to our interactants of (near) similar or different age (older vs. younger). As a rule, these norms tend to be consensually accepted, relatively firm and pervasive (Tajfel 1979).

SALIENCE: Relative age principle operates in situations in which I consider the physical age of the conversation partner, compare and associate it with my age.

CODE CONFIGURATION: In this stage, cognitive-evaluative operations need to get involved in order to identify (assume) my interactant's physical age and to correlate it with mine, i.e.as being (near) similar to mine, identical with mine, different from mine (younger or older).

The respondents were asked to express their preference in $\mathrm{T}$ or $\mathrm{V}$ forms in conversation with someone who is the same age, younger, significantly younger, older, or significantly older, irrespective of their physical age. The data show balanced results in the significantly younger and significantly older age groups in NSE and NSS respondents and differing results in that in the native speakers of Slovak a tendency to formal linguistic behavior was observed. The differing results for the criterion of relative age are as follows (Table 4). 
Table 4

Relative age principle

\begin{tabular}{|l|c|c|c|c|}
\hline & $\begin{array}{c}\text { Same age \& younger } \\
\text { formal }\end{array}$ & $\begin{array}{c}\text { Same age \& younger } \\
\text { Informal }\end{array}$ & Older formal & Older informal \\
\hline NSE & $0.00 \%$ & $100.00 \%$ & $9.00 \%$ & $81.00 \%$ \\
\hline NSS & $15.60 \%$ & $84.40 \%$ & $59.40 \%$ & $40.60 \%$ \\
\hline
\end{tabular}

\subsubsection{Network membership principle}

FRAME: Principles for specifying verbal expression of social distance.

PRE-UNDERSTANDING: Network membership principle implies considering the person a regular and accepted member within a group I belong to. The underlying conceptualization of the principle refers to "the social group as a collection of individuals who identify themselves as members of a social category sharing some emotional involvement in their common definition of themselves, and achieve some degree of social consensus about the evaluation of their group and of their membership of it" (Tajfel 1979: 40) ${ }^{1}$. This type of social categorization serves as a cognitive tool for segmenting and systematizing the social reality and providing an orientation tool for selfreference (Tajfel 1979).

SALIENCE: Network membership principle operates in situations in which I consider the network membership of the conversation partner, compare and associate it with mine.

CODE CONFIGURATION: In this stage, cognitive-evaluative operations need to get involved to identify my interactant's network membership and to juxtapose it with mine, i.e. identify our relationship as in-group vs. out-group and, consequently, adhere to appropriate communication norms.

The respondents were asked to express their preference in the usage of $\mathrm{T}$ or $\mathrm{V}$ forms based on whether as in-group members they share 1/ pastime activities, hobbies, 2/ work-related interests, or 3/ both pastime activities and work interests. The questionnaire data reveal that the principle under consideration is conceptualized and manifested in a very similar communication norm, namely the adherence to $\mathrm{T}$ forms in $100 \%$ in NSE and to informal language in $98 \%$ in NSS. The balanced results achieved in the study imply that this principle may universally operate across cultures. In addition, it is in accord with the findings of other communication studies showing that the individuals highly identified with their ingroups tend to communicate more formally with the out-group members (exhibiting more social distance) and informally (exhibiting less social distance) with the ingroup member.

1 The notion of group (network) membership is treated within his paradigm of social identification theory which is present in socio-political discussions and research on the issues of social inclusion and exclusion. Gradually the term acquired more negative connotation due to its application in socio-political research on the discrimination and inequality. We have adopted the concept and applied it to the present research as a notion void of any negative connotation and referring to cognitive-evaluative tool necessary in order to allocate Self on a social map. 


\subsubsection{Social identification principle}

FRAME: Principles for specifying verbal expression of social distance.

PRE-UNDERSTANDING: Social identification principle implies considering whether I perceive this person to be similar or different from me. The principle is closely interconnected to the notion of social identity structured as an interface between three socio-operative notions of social categorization, social identification, and social comparison. Social categorization (Tajfel 1979) as a cognitive and evaluative tool is used in order to understand the social environment in terms of social stratification categories. Social identification (a process of categorizing oneself into the group they belong to) builds on the acquired and experienced knowledge of social stratification and presupposes social comparison. Once a person has categorized themselves as part of a group within a social stratification system and has identified with that group, they exercise comparison of that group with other groups.

SALIENCE: Social identification principle operates in situations in which I delineate social status of the conversation partner, compare and associate it with the social status of mine.

CODE CONFIGURATION: In this stage, cognitive-evaluative operations are carried out to clarify my and conversational partner's social status and to interrelate them in terms of the following social status interrelations types: social status similar to mine, identical to mine, different from mine, very different from mine.

The respondents were asked to express their preference in the usage of $\mathrm{T}$ or $\mathrm{V}$ forms according to the social status of their conversation partner; the options were as follows: similar to mine, identical as mine, different from mine, and very different from mine. The questionnaire data reveal that the principle under question is structured and verbalized differently in the two lingua-cultures. Two thirds of native speakers of English use it as an autonomous principle; on the contrary, within the Slovak lingua-culture, two thirds of the native speakers of Slovak claimed that supplementary criteria would be necessary to make a proper choice.

\subsubsection{Address mode accommodation principle}

FRAME: Principles for specifying verbal expression of social distance.

PRE-UNDERSTANDING: Address mode accommodation principle implies the idea of what influence it has on my linguistic behavior if the person uses $\mathrm{T} / \mathrm{V}$ or a $\mathrm{T} / \mathrm{V}$-like address with me. Address mode accommodation principle as one of the fundamental social skills of adapting and/or non-adapting to certain communicative situation can be regarded as an integral constituent of communicative competence and linguistic behavior. Non-adaptation to communicative style and linguistic behavior of the conversational partner does not necessarily mean that a language user does not possess this skill.

SALIENCE: Accommodation and/or non-accommodation to a communicative situation ( $c f$ Giles \& Soliz, 2014) is a result of its complex evaluation and 
involves the cognitive-evaluative analysis of all six aforementioned principles.

CODE CONFIGURATION: The task is to conceptualize lingua-cultural rules of symmetry standing for address mode accommodation and of asymmetry expressing address mode non-accommodation.

The respondents were asked to consider two situations: Do you ever find yourself in the following situations? 1/ The conversation partner treats me in an informal way; I treat him/her in a formal way. 2/ The conversation partner treats me in a formal way; I treat him/her in an informal way. They were supposed to answer by selecting one of the frequency words on a scale (never, sometimes, often, very often). The questionnaire data evidence the absence of the address mode accommodation in the linguistic behavior of the native speakers of English $(0 \%$ of respondents use the asymmetry); the answers provided by the native speakers of Slovak show that the asymmetry of this kind may well be relatively common (43.8\% of NSS respondents exercise the address mode of non-accommodation).

\subsection{Summary and discussion}

The research problem of identifying informal $(\mathrm{T})$ and formal $(\mathrm{V})$ linguistic conduct in the English-based lingua-culture necessitates the analysis that we have decided to undertake by means of a four-point conceptualization scheme. The mere analysis comprised 3 sub-analyses. Firstly, our view is that the starting point is placing the concept of social distance in the framework of lingua-cultural identity. It follows that this concept is expressed by means of $\mathrm{T}$ and $\mathrm{V}$ forms that must be used in a particular lingua-culture based on certain principles. The analysis of this concept has yielded the task to identify the principles.

Secondly, the concept of $\mathrm{T}$ and $\mathrm{V}$ forms can be framed into social distance. They are used based on certain principles controlling discursive practices; we have opted to specify the principles in compliance with Clyne, Norrby \& Warren (2009: 158): familiarity principle, maturity principle, relative age principle, network membership principle, social identification principle, address mode accommodation principle. So, to proceed with analysis, it is necessary to identify relationship types within each principle.

Thirdly, we analyzed each principle. All of them can be framed within social distance. Individually, they provide the understanding of relationships based on certain rules pertinent to a particular culture. We specified theses relationship types as follows:

- Familiarity principle: acquaintance, friend, close/distant relative, co-worker, boss in the lower/higher management.

- Maturity principle: someone I consider mature and an adult vs. someone I do not consider so.

- Relative age principle: someone I consider approximately of my age, someone I consider younger/older, someone I consider significantly younger/older. 
- Network membership principle: someone I consider a regular and accepted member within a group I belong to, someone I do not consider so.

- Social identification principle: someone I consider socially similar to me vs. someone I consider socially different from me

- Address mode accommodation principle: I adapt to the T/V forms used by my conversation partner, I do not adapt to the $\mathrm{T} / \mathrm{V}$ forms used by my conversation partner.

Within the conceptualization scheme, the code configuration of each principle yields a task to identify socio-cultural restraints and lingua-cultural preferences. To do so, we designed two questionnaires; one for native speakers of English (hereinafter NSE) and one for those of Slovak (hereinafter NSS). The data provided the following results.

The familiarity principle shows interesting results in the relationship with boss in the lower management - for two thirds of the NSS, it is a formal relationship, while it is so only for one third of NSE. Another interesting result is in the notion of friend - for $100 \%$ of the NSS it represents an informal relationship, while for $9 \%$ of the NSE it may also represent a formal relationship. Regarding the length of a relationship, the NSE expressed a much quicker transition to an informal relationship than the NSS - in a long relationship, $27 \%$ of NSE in comparison with $53 \%$ of NSS keep the relationship formal. This can be seen in the fact that in short relationship only $6 \%$ of NSS in comparison with $27 \%$ of NSE switch to an informal relationship.

The maturity principle supports the results of the familiarity principle. If the NSE considered the interactant mature, $54.5 \%$, in comparison to only $6 \%$ of NSS, would behave informally. The relative age principle shows very similar results. If the NSE considered an interactant same age and younger, all of them, in comparison with $84 \%$ of NSS, would behave informally. If the NSE considered an interactant older, $81 \%$ of them, in comparison with $41 \%$ of NSS would behave informally. The network membership principle shows balance in the results between NSE and NSS. The social identification principle has a different standing in the two cultures: the NSE can easily identify with other interactants, the NSS cannot decide based just on this principle (two thirds of them would need supplementary criteria). The address accommodation principle shows differing approaches in the two cultures: $100 \%$ of the NSE express the symmetry in the relationship, while $44 \%$ of the NSS expressed they accept asymmetry, irrespective in which direction.

The claimed research problem of T/V address rules being dispersed in Englishbased lingua-cultures may as well lie in the fact that the English lingua-culture tolerates or even supports fast transition and accommodation to the interactant's (non/)linguistic conduct, social closeness rather than distance in verbal expression, yet not necessarily in the true nature of a relationship. Such lingua-cultural rules may well be in sharp contrast with other lingua-cultures, as it can be seen in the example of the Slovak language in the present study. 


\section{Conclusion}

In our quest for the answer to the $1^{\text {st }}$ research question (What is embodied in the concept of social distance and/or (in)formality in communication in a specific lingua-cultural identity?) our point of departure was the concept of a lingua-cultural identity whose function in expressing (in)formal relationship with a respective communication partner is the concept of social distance. Two research tools were applied in order to conceptualize this notion, namely a hierarchical conceptualizing scheme of a set of principles encapsulated in the said notion, and a follow-up questionnaire investigating the preferences in NNS and NSE usage of informal vs. formal ways of communication. In our quest for the answer to the $2^{\text {nd }}$ research question (What are the implications in case the encounter of two cultural identities occurs?) we referred to the analyses of the conceptualizing schemes employed for a set of principles and linked them with the questionnaire data. The present study indicates that the conceptualizing process may as well be of hierarchical nature. Thus, the mere conceptualization of $\mathrm{T}$ vs. $\mathrm{V}$ or informal vs. formal may emanate from the conceptualization of social distance in terms of a set of principles, the conceptualization of the specific principle in terms of the relationship types, the conceptualization of the relationship type in terms of a specific culture and the conceptualization of a culture-specific relationship type through language means ( $\mathrm{T}$ or $\mathrm{V}$ ). Frequent involvement in communication acts using more than a single language may be viewed upon as an encounter of two or more cultures, which may impact an individual's identity. In time, the mind of each individual acquires a new quality of the so-called common underlying conceptual base (Kecskes \& Papp 2000) and thus may be treated as bi(multi)lingual and bi(multi)cultural from a socio-pragmatic perspective. Regarding a culture-specific relationship type ( $\mathrm{T}$ or $\mathrm{V}$ ), in order to arrive at its conceptualization in other than an individual's lingua-culture, a multilingual's mind has to be open to the (hierarchical) conceptualization process and be able to opt for appropriate language means (be it overt syntactic, morphological or lexical means or an amalgam of dispersed features).

(C) Magdaléna Bilá, Alena Kačmárová, and Ingrida Vaňková, 2020
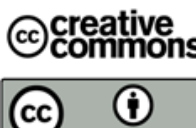

This work is licensed under a Creative Commons Attribution 4.0 International License https://creativecommons.org/licenses/by/4.0/

\section{Acknowledgment}

The present research study is part of research activities conducted within a research grant project KEGA 007PU-4/2019 "Defining a writing style of scholarly papers written in English vs. Slovak/Slavic lingua-culture conventions.” 


\section{REFERENCES}

Bilá, Magdaléna, Alena Kačmárová \& Marianna Kraviarová. 2018. Expressing social deixis through prosody. A case study of American English. SKASE Journal of Theoretical Linguistics. 15 (1). 80-93. [Electronic resource]. URL: http: www.skase.sk/Volumes/ JTL36/index.html.

Chiluwa, Innocent. 2010. Discursive Practice and the Nigerian Identity in Personal Emails. In Rotimo Taiwo (eds.), Handbook of Research on Discourse Behavior and Digital Communication: Language Structures and Social Interaction. 1st edn, 112-129. DOI: 10.4018/978-1-61520-773-2.ch007

Clyne, Michael, Catrin Norrby \& Jane Warren. 2009. Language and Human Relations (Styles of Address in Contemporary Language). Cambridge: Cambridge University Press.

Fairclough, Norman. 1992. Discourse and Social Change. Cambridge: Polity Press.

Foucalt, Michel. 2001. Madness and Civilization: A History of Insanity in the Age of Reason. London: Routledge.

Foucalt, Michel. 2010. The Archeology of Knowledge: and the Discourse on Language. New York: Vintage books.

Giles, Howard \& Soliz Jordan. 2014. Communication Accommodation Theory - A Situated Framework for Relational, Family, and Intergroup Dynamics. In Leslie Baxter \& Dawn O. Braithwaite (eds.), Engaging Theories in Interpersonal Communication: Multiple Perspectives. 157-169. Thousand Oaks: Sage Publications. [Electronic resource]. URL: https://www.researchgate.net/publication/284957847_Communication_accommodation_ theory_a_situated_framework_for_interpersonal_family_and_intergroup_dynamics.

Grosjean, François. 1985. The bilingual as a competent but specific speaker-hearer. Journal of Mul-tilingual and Multicultural Development 6. 467-477.

Hall, Edward T. 1983. The dance of Life: the other Dimension of Time. Garden City, N.Y.: Anchor Press.

Haugh, Michael. 2013. Speaker Meaning and Accountability in Interaction. Journal of Pragmatics 48 (1). 41-56. [Electronic resource]. URL: http://www.sciencedirect.com/ science/article/pii/S0378216612002925.

Hoffman, Charlotte. 1991. An Introduction to Bilingualism. Longman.

Hofstede, Geert. H. 1994. Cultures and Organizations: Software of the Mind: Intercultural. London: Harper Collins.

Kačmárová, Alena, Magdaléna Bilá \& Ingrida Vaňková. 2018. The Conceptualizing of Conceptualization (of linguistics metalangue). Prešov: Prešovs.ká univerzita. [Electronic resource]. URL http://www.pulib.sk/web/kniznica/elpub/dokument/Kacmarova6.

Kecskes, Istvan \& Tunde Papp. 2000. Foreign Language and Mother Tongue. New York, London: Psychology Press, Taylor \& Francis Group.

Kirschner, Suzanne \& Jack Martin. 2010. The Sociocultural Turn in Psychology: The contextual Emergence of Mind and Self. New York: Columbia University Press.

Komlósi, László I. 2003. In Quest of Cultural and Conceptual Universals for Situated Discursive Practice. In László Komlósi, Peter Houtlosser \& Leezenberg Michiel (eds.), Communication and Culture Argumentative, Cognitive and Linguistic Perspectives. 159-176, Amsterdam, Sic Sat.

Kortvélyessy, Lívia. 2010. Vplyv sociolingvistických faktorov na produktivitu v slovotvorbe [The impact of sociolinguistic factors on productivity in word-formation]. Prešov: Slovacontact.

Larina, Tatiana. 2015. Culture-Specific Communicative Styles as a Framework for Interpreting Linguistic and Cultural Idiosyncrasies. International Review of Pragmatics 7 (5). Special Issue: Communicative Styles and Genres. 195-215. 
Larina, Tatiana V., Vladimir I. Ozyumenko, \& Svetlana Kurteš. 2017. I-identity vs. we-identity in language and discourse: Anglo-Slavonic perspectives. Lodz Papers in Pragmatics 1 (1). $109-128$.

Leidy, Melinda S. \& Ross D. Parke. 2015. Socialization in Infancy and Childhood. International Encyclopedia of the Social \& Behavioral Sciences. 2nd edn. 866-872. Elsevier.

Leite de Oliviera, Maria do Carmo \& Carla Mirelle de Oliveira Matos Lisboa. 2017. Narratives about displacement and stigmatization of identities. Russian Journal of Linguistics 21 (2). $320-334$.

Moghadam, Valentine M. 2018. Introduction: Women and identity in Theoretical and Comparative Perspective. Identity Politics and Women: Cultural Reassertions and Feminisms in International Perspective. Routledge. New York.

Resta, Simonetta. 1998. Words and social change. The impact of power and ideology on the language of Economics and Law, 19-22. ASpla revue du GERAS. Théorie et pratique des discours spécialisés. [Electronic resource]. URL: http://journals.openedition.org/asp/ 2760. DOI: 10.4000/asp.2760.

Ricoeur, Paul. 1974. The Conflict of Interpretations: Essays in Hermeneutics. Evanson: Northwestern University.

Ricoeur, Paul. 1976. Interpretation Theory: Discourse and the Surplus of Meaning. Fort Worth: Texas Christian University.

Rhee, Seongha. 2019. Politeness Pressure on Grammar: The Case of First and Second Person Pronouns and Address Terms in Korean. Russian Journal of Linguistics 23. 950 - 974. DOI: 10.22363/2687-0088-2019-23-4-950-974.

Spencer-Oatey, Helen. 2000. Culturally Speaking: Managing Report through Talk across Cultures. London: Continuum.

Tajfel, Henri \& John Turner. 1979. An Integrative Theory of Intergroup Conflict. In William G Austin. \& Stephen Worchel (eds.), The Social Psychology of Intergroup Relations, 33-47. Monterey, CA: Brooks/Cole. [Electronic resource]. URL: http://www.ark143.org/ wordpress2/wp-content/uploads/2013/05/Tajfel-Turner-1979-An-Integrative-Theory-ofIntergroup-Conflict.pdf

Taylor, Charles. 1985. Philosophical papers I.: Human Agency and Language. Cambridge: Cambridge University Press.

Valeyeva, Alsu. 2014. Linguistic Behavior as a Social and Cultural Potential in the Multiethnic Community. Procedia - Social and Behavioral Sciences 149, 984-989. [Electronic resource]. URL: https://www.researchgate.net/publication/275544460_Linguistic_ Behavior_as_a_Social_and_Cultural_Potential_in_the_Multiethnic_Community

Van Dijk, Teun A. 2006. Ideology and discourse analysis. Journal of Political Ideologies 11(2). $115-140$

Vaňko, Juraj (eds.) 2014. Obraz človeka v jazyku. [A human being's reflection in language] Nitra: Univerzita Konštantína Filozofa, Filozofická fakulta. Faculty of Arts, Constantine the Philosopher University in Nitra.

\section{Article history:}

Received: 27 January 2020

Revised: 18 March 2020

Accepted: 25 March 2020 


\section{История статьи:}

Дата поступления в редакцию: 27 января 2020

Дата принятия к печати: 25 марта 2020

\section{Bionotes:}

MAGDALÉNA BILÁ is Dr. of Philology, Full Professor at the Institute of British and American Studies, Faculty of Arts, The University of Prešov in Prešov. Her research interests include comparative and contrastive studies (juxtaposing English and Slovak), discourse analysis, and translation studies (conceptualization in a source and a target language).

\section{Contact information:}

Institute of British and American Studies, Faculty of Arts, University of Prešov, 17 Novembra Street 1, 08001 Prešov, Slovakia e-mail: magdalena.bila@unipo.sk

ALENA KAČMÁROVÁ is Dr. of Philology and Full Professor at the Institute of British and American Studies, Faculty of Arts, The University of Prešov in Prešov. Her research interests include comparative and contrastive studies (juxtaposing English and Slovak), discourse analysis, and intercultural and conceptual pragmatics.

\section{Contact information:}

Institute of British and American Studies, Faculty of Arts, University of Prešov, 17 Novembra street 1, 08001 Prešov, Slovakia

e-mail: alena.kacmarova@unipo.sk

INGRIDA VAŇKOVÁ is Dr. of Philology, Assistant Professor at the Institute of British and American Studies, Faculty of Arts, The University of Prešov in Prešov. Her research interests include comparative and contrastive studies (English and Slovak lexicology, phraseology, and word formation), text hermeneutics, and translation studies.

\section{Contact information:}

Institute of British and American Studies, Faculty of Arts, University of Prešov, 17 Novembra street 1, 08001 Prešov, Slovakia

e-mail: ingrida.vankova@unipo.sk

\section{Сведения об авторах:}

МАГДАЛЕНА БИЛА - доктор филологических наук, профессор Института британских и американских исследований гуманитарного факультета Прешовского университета в Прешове. Ее научные интересы включают сопоставительное языкознание (сопоставление английского и словацкого языков), анализ дискурса и переводоведение.

\section{Контактная информация:}

Institute of British and American Studies, Faculty of Arts, University of Prešov, 17 Novembra street 1, 08001 Prešov, Slovakia

e-mail: magdalena.bila@unipo.sk 
АЛЕНА КАЧМАРОВА - доктор филологических наук, профессор Института британских и американских исследований гуманитарного факультета Прешовского университета в Прешове. Ее научные интересы включают сопоставительные исследования (сопоставление английского и словацкого языков), анализ дискурса, а также межкультурную и когнитивную прагматику.

Контактная информация:

Institute of British and American Studies, Faculty of Arts, University of Prešov, 17 Novembra street 1, 08001 Prešov, Slovakia

e-mail: alena.kacmarova@unipo.sk

ИНГРИДА ВАНЬКОВА - доктор филологических наук, доцент Института британских и американских исследований гуманитарного факультета Прешовского университета в Прешове. Ее исследовательские интересы включают сопоставление английской и словацкой лексикологии, фразеологии и словообразования, герменевтику текста и переводческие исследования.

Контактная информация:

Institute of British and American Studies, Faculty of Arts, University of Prešov, 17 Novembra street 1, 08001 Prešov, Slovakia

e-mail: ingrida.vankova@unipo.sk 